\title{
MENTAL CRUELTY AS A GROUND FOR DIVORCE
}

7 HERE HAS ALWAYS BEEN a reluctance on the part of the courts to interfere with family life. ${ }^{1}$ Marriage, since earliest times, has been linked with religious dogma and standards of behavior; ${ }^{2}$ consequently, it is not unusual to find that as the English judicial system developed, the duties of marital counsel as well as adjudication were exercised by the ecclesiastical courts ${ }^{3}$ and by the legislature; ${ }^{4}$ nor is it startling that there was great reluctance on the part of the bishop in the ecclesiastical court to extend the scope of authority by which the laity could sever the bonds "which Heaven hath made." This close relationship between spiritual concepts and the marital status has provided a most formidable barrier to the development of effective divorce law.

Since there were no ecclestiastical courts included in the American judicial structure, and because equity courts declined jurisdiction over divorce matters in the absence of special statutory authority, ${ }^{6}$ the legislatures of the several states assumed supervision over the granting of divorce decrees. ${ }^{7}$ Thus, in the early history of the United States, legislative grant was the sole practicable means by which an effective divorce decree might be obtained, and petition to the legislature for divorce was common practice. As the demand for divorces became more prevalent, the burden of this practice became more onerous until, finally, the legislatures delegated divorce administration to the courts. ${ }^{8}$ The aim of these delegating statutes was to open the door to an easier solution for a most delicate problem; the result has been a confused and incongruous body of law.

Much of the confusion in divorce law stems from the inability of judges to alleviate pressing marital problems in the face of restrictive statutes. So well defined are the statutory grounds for divorce that

${ }^{1}$ See Howard, A History of Matrimonial Institutions 3-xI7 (1904).

2 See generally KITChen, A History of Drvorce (1912).

32 BL. COMM. 440.

4 Pollock and Maitland, History of Eng. LaW (2d Ed. 1898) p. 385.

"That "marriages are made in heaven" was long the prevailing philosophy of the English ecclesiastical courts. See Pollock and Martland, note 4 supra, c. I for a detailed appraisal of the position of the ecclesiastical courts in marital matters.

${ }^{\circ}$ See Burtis v. Burtis, ${ }_{4}$ Am. Dec. $56_{3}$ (N.Y. Ch. 1825 ).

7 Jacobs and Goebel, Cases and Materials on Domestic Relations 379 (3 d ed. 1952 ).

${ }^{8} I d$. at 380 . Divorce by legislative grant is not entirely extinct; but it is so impracticable as to be rarely attempted. 
courts have been compelled to concoct, by loose interpretation of existing statutory requirements, grounds for divorce which were not within the contemplation of the drafters of the divorce statutes. The judicially created ground most frequently relied upon is that of mental cruelty. Under the early statutes physical injury, actual or menaced, was a requisite for divorce on the grounds of cruelty. ${ }^{\circ}$ Not until I 872 was there any judicial recognition that injury, other than actual physical injury, might be so unbearable as to warrant court dissolution of the marital relationship. ${ }^{10}$ However, once "mental cruelty" was introduced as a ground for divorce, many courts were not loath to accept it as a make-shift panacea for legislative conservatism; ${ }^{11}$ and, finally, state legislatures have begun to accept the doctrine of mental cruelty. ${ }^{12}$

Since divorce statutes and judicial interpretations thereof differ from state to state, it is impossible to formulate an all-inclusive definition of mental cruelty sufficient to warrant divorce. The best that can be done, perhaps, is to examine the various types of relevant statutory provisions and the manner in which they have been applied in various fact situations.

\section{The Statutes}

Divorce law is characterized by an amazing lack of statutory uniformity with regard to cruelty as a ground for divorce. Demonstrative of this lack of uniformity is such non-definitive statutory phraseology as: "extreme cruelty,"13 "cruel and inhuman treatment,"14 "extreme

${ }^{\circ}$ Evans v. Evans, I Hag. Cons. 35, 161 Eng. Rep. 466, 467 (1790) wherein Lord Stowell stated: "What merely wounds the feelings is in few cases to be admitted, where not accompanied by bodily injury, either actual or menaced. Mere austerity of temper, petulence of manner, rudeness of language, a want of civil attention and accommodation, even occasional sallies of passion, if they do not threaten bodily harm, do not amount to legal cruelty; they are high moral offenses in the marriage state, undoubtedly; not innocent in any state of life; but they are not that cruelty against which the law can relieve. Under such misconduct of either of the parties, for it may exist on one side as well as the other, the suffering party must bear in some degree the consequences of an unjudicious connection; must subdue by decent resistant or by prudent conciliation; and if this cannot be done, both must suffer in silence."

${ }^{10}$ Birch v. Birch, $x$ Rob. Ecc. 675, x63 Eng. Rep. 1175 (1872).

${ }^{11}$ In $1932,42.7$ percent of all divorces in the United States were granted on grounds of cruelty. 1932 BUREAU OF THE CENSUS REPORT. In recent years, courts in jurisdictions which offer no statutory opening for granting divorces on grounds of mental cruelty have been stretching the statutory language in order to make room for such a ground. See note, 19 ORE. L. REV. 341 (1939).

${ }^{12}$ See appendix infra.

${ }^{13}$ In statutes of 17 jurisdictions: California, Delaware, Florida, Hawaii, Idaho, Montana, Nebraska, Nevada, New Hampshire, New Jersey, North Dakota, Ohio, Oklahoma, Oregon, Pennsylvania, Rhode Island, South Dakota. See Appendix infra.

${ }^{14}$ In statutes of six jurisdictions: Alaska, Indiana, Minnesota, New Mexico, Texas, Wisconsin. See Appendix infra. 
cruelty ... as to render cohabitation unsafe,"15 "habitual cruel and inhuman treatment,"16 "extreme and repeated cruelty,"17 "cruelty of treatment,"18 and "intolerable cruelty."19 It is well to note that many of these statutory "definitions" make no distinction between physical cruelty and mental cruelty-leaving to the courts the task of deciding whether mental cruelty alone is sufficient under the statutory language. In fact, in only nine states do statutes make specific reference to mental cruelty as a ground for divorce. ${ }^{20}$ Statutes in ten other jurisdictions, however, provide for divorce in cases of "personal indignities rendering life burdensome," a peg upon which situations amounting in other states to mental cruelty may conveniently be hung. ${ }^{21}$ And judicial construction placed upon "indignities" is generally so similar to that placed on mental cruelty that it will not be treated separately.

\section{Judicial Interpretation}

The modern definition of "mental cruelty" has evolved from two distinct judicial techniques. On the one hand, the courts have characterized as necessary ingredients of "mental cruelty" various factors which are commonly present in situations of marital discord. On the other hand, they have approached the problem by defining "mental cruelty" not so much in terms of component factors, but rather by determining whether a certain course of conduct is so anti-social or so out of harmony with our traditions of marriage that it warrants a divorce decree.

Factors Considered Important

Necessity for Resulting Physical Injury and/or Injury to the Health of Complainant.

A review of the cases reveals that in some states, as indicated by the Appendix, cruelty is tantamount to physical cruelty. In a second group ${ }^{22}$ mental cruelty is recognized, but only where it has impaired the complainant's health. ${ }^{23}$ In a third group, the courts have construed cruelty to include both physical and mental attacks upon the innocent spouse. ${ }^{24}$

\footnotetext{
${ }^{16}$ Delaware. See Appendix infra.

${ }^{17}$ Illinois. See Appendix infra.

${ }^{16}$ Mississippi. See Appendix infra.

${ }^{18}$ Maryland. See Appendix infra.

${ }^{10}$ Connecticut. See Appendix infra.

${ }^{\text {so }}$ Statutes in California, Colorado, Montana, South Dakota, and Utah refer specifically to "mental cruelty," while the Arizona, Michigan, Nebraska, and Wisconsin statutes are here included because they refer to cruelty, whether by use of personal violence "or by other means" (emphasis added). See Appendix infra.

${ }^{21}$ Alaska, Arkansas, Hawaii, North Carolina, Oregon, Pennsylvania, Tennessee, Washington, Wyoming. See Appendix infra.

${ }^{22}$ See cases cited in note 3 I infra.

${ }_{23}$ The "injury to health" requirement was first expressed by Lord Stowell in Evans v. Evans, x Hag. Cons. 35, I6r Eng. Rep. 466 ( 1790 ), note 9 supra.

24 The California court, for example, had previously allowed itself to be confined
} 
The more liberal view was expressed by the Oklahoma court in Routh v. Routh, ${ }^{25}$ where a husband was granted a divorce, despite no showing of physical injury, on the grounds that his wife engaged in annoying and accusatory conversations with husband's friends and threatened to kill complainant. The court wrestled with the factor of physical injury and concluded that it was unnecessary to give cause for divorce. Similarly, in Georgia "cruel treatment" has been construed to mean the infliction of either physical or mental pain without the requirement of actual physical injury, ${ }^{26}$ and, in a like manner, the courts of Florida, ${ }^{27}$ Indiana, ${ }^{28}$ Iowa, ${ }^{29}$ and Kentucky ${ }^{30}$ have dispensed with the necessity for acts resulting in physical injury. Thus, the modern trend seems to lead away from physical injury requisites.

A further requisite, perhaps more prevalent than that of physical injury, is that the health of the complaining spouse be adversely affected by the acts of the other. The most frequently announced view is that there must have been injury to the complainant's health, or that such injury is imminent if the acts complained of are continued, ${ }^{31}$ or that there is a reasonable apprehension on the part of complainant that in-

by historical demands for cruel acts evidenced by physical injury. Waldron v. Waldron, 85 Cal. $25 \mathrm{I}, 24$ Pac. 649 ( 1890 ). The Waldron case was later determined to be overly confining in Barnes v. Barnes, 95 Cal. 17 1 , 30 Pac. 298 (1892). See also Fleming v. Fleming, 95 Cal. 430, 30 Pac. 566 (1892); Cooper v. Cooper, I 7 Mich. 204 (I868). California has recently overruled its previous limitations, and now holds that mental suffering alone may constitute extreme suffering within the meaning of the California statute. McFall v. McFall, 588 Cal. App.2d 208, I36 P.2d 580 (194.3).

${ }^{25}$ Routh v. Routh, 191 Okla. 419, 130 P.2d 1000 (1942).

${ }^{20}$ Holcombe v. Holcombe, 197 Ga. 105, 27 S.E.2d 687 (I943).

${ }^{27}$ Baldwin v. Baldwin, I5 Fla. 314, 9 So.2d 717 ( 1942 ).

${ }^{28}$ Mendenhall v. Mendenhall, I 6 Ind. App. 545, 64 N.E.2d 806 (1946).

${ }^{29}$ Dillavou v. Dillavou, 235 Iowa $634, x 7$ N.W.2d 393 (1945).

${ }^{30}$ Ezell v. Ezell, $260 \mathrm{Ky}$. 775, 776, 86 S.W.2d 998, 999 (1935) wherein the court stated, "The constant ding dong of the charge he [defestant, husbaud] made, day in aud day out, month in and month out, year in and yess out and compelling her [complainant, wife] to live under constant espionage, were enough to drive her mad and the court did not err in granting her a divorce."

${ }^{31}$ Waltenberg v. Waltenberg, 298 Fed. $8_{42}$ (D.C. Cir. 1924); Carr v. Carr, 17 I Ala. 600, 55 So. 96 (I9II); Crum v. Crum, 57 Cal. App. 539, 207 Pac. 506 (1922); Baker v. Baker, 94 Fla. roor, 114 So. 661 (1927); Thompson v. Thompson, i 86 Iowa 1066, 173 N.W. 55 (r919); Johnson v. Johnson, r83 Ky. 421, 209 S.W. 385 (1919); Krauss v. Krauss, I6 6 La. 2 18, Ix So. 683 (1927); McCue v. McCue, 191 Mich. 1 , 157 N.W. ${ }^{6} 69$ (1916); Faris v. Faris, 107 Neb. 214,185 N.W. 347 (1921); McLaughlin v. McLaughlin, 48 Nev. 153, 238 Pac. 402 (1925); Pearson v. Pearson, 230 N.Y. I4I, I29 N.E. 349 (1920); Robertson v. Robertson, 73 Okla. 299, I76 Pac. 387 (I918); Heinemann v. Heinemann, I 8 Ore. 178, 245 Pac. 1082 (1926); Borda v. Borda, 44 R.I. 337, II7 Atl. 362 (I922); Burt v. Burt, 26I S.W. 407 (Tex. Civ. App. 1924); Elder v. Elder, 139 Va. 19, 123 S.E. 369 (1924); White v. White, ro6 W. Va. 680,146 S.E. 720 (1929). 
jury to health will result." ${ }^{32}$ These "injury to health" requirements, while appearing less onerous than other necessary factors at first glance, would be rendered even more formidable were it not for the fact that the courts require little proof of injury to health ${ }^{33}$ or assume such injury without proof. ${ }^{34}$ Thus, while Connecticut requires a complainant to show, by a preponderance of evidence, injury to health, ${ }^{35}$ the courts of Massachusetts, ${ }^{36}$ Michigan, ${ }^{37}$ Minnesota, ${ }^{38}$ and Rhode Island ${ }^{39}$ pay but lip service to this requirement, being easily persuaded that such injury has occurred or will result.

\section{Necessity for Malicious Intent.}

Some courts hold that malice is an essential element of mental cruelty which the divorce-seeking party must establish. The presence of some degree of malicious intent on the part of one of the spouses makes it less difficult for the court to rationalize its decree in the face of restrictive statutory provisions. ${ }^{40}$ To be sure, that degree of malice necessary to constitute cruelty falls short of malice requirements in other phases of the law; ${ }^{41}$ yet, in the absence of any showing of malice whatsoever, some courts will deny a divorce solely for that reason. ${ }^{ \pm 2}$

${ }^{32}$ McNeill v. McNeill, 125 Miss. 277,87 So. 645 (192x).

${ }^{33}$ Walstrom v. Walstrom, 124 Fla. 366,168 So. 532 (1936).

34 Aitcheson v. Aitcheson, 99 Iowa 93, 68 N.W. 373 (1896).

${ }^{35}$ Shaw v. Shaw, 17 Conn. I 89 ( 1845 ); see also Latham v. Latham, 30 Gratt. 307 (Va. $\times 878$ ). Contra: Fleming v. Fleming, 95 Cal. 430, 30 Pac. 566 (1892).

${ }^{30}$ Rudnick v. Rudnick, 288 Mass. 256, 192 N.E. 501 (1934). ("It is settled law in this Commonwealth that cruelty ... . for divorce may exist without blows and is proved if the acts charged create danger to the person or health. It may consist of angry, coarse and abusive language... or unreasonable exercise of marital rights of sexual intercourse. ... To establish cruel and abusive treatment ... it being sufficient to prove that such [injury to health] was the natural consequence of his conduct and that harm ... was reasonably likely to follow. . . "); Lyster v. Lyster, III Mass. 327 (1873).

${ }^{37}$ Thomas v. Thomas, 247 Mich. 487, 226 N.W. 230 (1929).

${ }^{38}$ Tschida v. Tschida, 107 Minn. 235, 212 N.W. 193 (1927).

${ }^{30}$ Bastien v. Bastien, I89 Atl. 37 (Sup. Ct. R.I. 1937).

to Dahnke v. Dahnke, 55 Cal. App. 12, 202 Pac. 894 (1921); Lowry v. Lowry, I 70 Ga. 349, I53 S.E. I I (I930); Heinemann v. Heinemann, I 8 Ore. I78, 245 Pac. 1082 (1926).

${ }^{41}$ Rebstock v. Rebstock, I44 N.Y. Supp. 289 (1913) (wherein the court attempted to define the malice element in cruelty: "Cruelty involves the idea of wantonness, that an act is done willfully and for the purpose of inflicting suffering.").

42 Armstrong v. Armstrong, 229 Mass. 592, II8 N.E. 916 (1918); Philley v. Philley, 207 Mich. 672, 175 N.W. $5_{58}$ (I919) (where acts complained of resulted from the disposition of the spouse and were not controllable, therefore not intentionally motivated); Heim v. Heim, 35 Ohio App. 408, I72 N.E. 45 I (1930) (where offending spouse was not completely sane the court held that a lunatic cannot be held accountable if he does not understand the nature of his acts); Grey v. Grey, II 3 Pa. Super. 215, 172 Atl. 4I2 (1934) (where the wife's cruel acts resulted from illness brought on by 
In an early Connecticut case, ${ }^{43}$ for example, the court denied a divorce where complainant proved serious impairment to her health because of cruel treatment by her husband, but failed to establish, prima facie, the presence of malice or knowledge on the part of defendant that injury would result. It was nearly a century before the courts of Connecticut could avoid the import of the earlier precedent and recognize that cruel treatment necessarily includes at least implied malice. ${ }^{44}$

\section{Necessity for Persistency of Conduct.}

A troublesome question for the courts has been whether repeated acts of cruelty are necessary in order to meet statutory requirements. In at least three states, statutes explicitly require continual abuse in order that cruelty sufficient to justify divorce be established. ${ }^{45}$ This view appears to be in accord with the weight of authority, even absent express statutory provision. ${ }^{46}$ Generally, unless the cruel treatment is in itself outrageous, ${ }^{47}$ or will result in serious and permanent injury to complainant, ${ }^{48}$ or will, in the determination of the court, continue unless judicially abated, ${ }^{49}$ single acts of cruelty will not entitle one to a divorce decree.

husband's conduct). But see: Grierson v. Grierson, 156 Cal. 434, 105 Pac. 120 (1909); Rudnick v. Rudnick, 288 Mass. 256, 192 N.E. 501 (1934) (Divorce granted bẹcause of husband's uncontrollable lust); McNeil v. McNeil, 125 Miss. 277, 87 So. 645 (1921); Robinson v. Robinson, 66 N.H. 600, 23 Atl. 362 (189r) (Where husband's health was impaired by wife who insisted upon curing him as a Christian Science healer).

${ }^{33}$ Shaw v. Shaw, 17 Conn. $189(1845)$.

44 Morris v. Morris, I32 Conn. 188, 43 A.2d 463 (1945); Babcock v. Babcock, I 7 Conn. 310,167 Atl. 815 (1933).

"Eentucky- "habitual behavior" for not less than six months unless it is apparent that by compelling the husband and wife to remain together there will be at serious threat that permanent injury will result; Illinois- "extreme and repeated cruelty" construed to preclude single acts of cruelty in Godfrey v. Godfrey, 284 IIl. App. 297, I N.E.2d 777 ( 1936 ) and even a repetition when there has been a lapse of eight years between the abuses in Shorediche v. Shorediche, II5 Ill. 102, 3 N.E. 736 (1885); Mississippi- "habitual cruel and inhuman treatment" as a general course of conduct rather than a single act in Manning v. Manning, 160 Miss. 318,133 So. 673 (1931). See Appendix infra.

${ }_{42} 7$ C.J.S., Divorce $\$ 25$ (b), at 548 .

"7 Gilbert v. Gilbert, 305 Ill. 216 , I37 N.E. 99 ( 1922 ) (calling wife a "whore" when she was ill); Linnell v. Linnell, I $_{43}$ N.E. 1 $_{3}$ (Mass. 1924) (where husband shot off a pistol in order to frighten wife).

${ }^{48}$ Rice v. Rice, 88 W. Va. 54, 106 S.E. 237 (1921) (such abuse by husband that wife was forced to run out of the house on a cold winter night).

${ }^{6}$ Trigo v. Trigo, 9o Fla. 60, 105 So. 123 (19:5); Curtiss v. Curtiss, 243 Mass. $5 \mathrm{I},{ }_{3} 6$ N.E. 829 ( 1922 ) (a showing of a reasonable apprehension that the acts were likely to continue and result in serious harm to complainant); Bamberg v. Bamberg, I23 N.J. Eq. 570, 199 Atl. 54 (1938); Frantz v. Frantz, 134 Pa. Super. 48 1, 3 A.2d 
Distinction Between Husband and Wife as Complainants.

Ordinarily, the courts maintain that when they grant or withhold divorce decrees on the grounds of mental cruelty they do so without regard to the sex of the complainant. However, the statutes of several states demonstrate a more lenient attitude when the wife is the complaining spouse than when the husband seeks the divorce. The Alabama statute, ${ }^{50}$ for example, makes the cruelty ground available solely to the wife, and only for a divorce a mensa; the Tennessee statute ${ }^{61}$ provides for a divorce, a mensa, to the wife where the husband has rendered intolerable indignities; the Iowa Code ${ }^{52}$ allows divorce on grounds of cruelty where there exists such "inhuman treatment as to endanger the life of the wife" (emphasis added). Although the statutes of Alabama, Tennessee, and Iowa are unique, the attitude frequently lurks in judicial opinions that there is, and should be, a distinction drawn between husband and wife complainants with regard to the degree of cruelty needed to satisfy the divorce requirements. ${ }^{53}$ Few courts are so bold in airing their inclinations toward favoring the female complainant as was the Utah court in Cordner v. Cordner ; ${ }^{4}$ but, whether or not the courts admit that they make such a distinction, they appear frequently to favor the woman at least with respect to the degree of proof required. ${ }^{55}$ For example, in a Louisiana case, ${ }^{56}$ where the husband

987 (1939). But see: Frites v. Frites, 138 Ill. 436, 28 N.E. 1058 (1891); Ramsey v. Ramsey, I62 Ky. 741, 172 S.W. 1082 (I915); Culp v. Culp, I64 S.W.2d 623 (Mo. App. 1942); Johnston v. Johnston, 260 S.W. 770 (Mo. App. 1924) (single threat to throw wife out the window when there was no attempt is insufficient. There must not only be an apprehension, but it must be reasonable.); Bounds v. Bounds, $135 \mathrm{Md}$. 220, ro8 Atl. 870 (1919); Philley v. Philley, 207 Mich. 672, I75 N.W. I58 (1919).

${ }^{\text {to }}$ See Appendix infra. ${ }^{51}$ Ibid.

62 Ibid.

${ }^{63}$ Sales v. Sales, 222 Ky. 175, 300 S.W. 354 (1927) wherein the court said: "Her cruelty was sufficient to justify him in leaving her, but cruelty by the wife is not a ground of divorce to the husband."

is gI Utah 466, 470, 61 P.2d 60I, 603 (1936). Here the court stated: "Some nagging and fault-finding by each spouse is to be expected, and the husband being the stronger, ought to forbear much of it with patience. ... What may be cruelty causing great mental distress in one case may not be in another. Each case must depend upon its own facts and circumstances. The adjudged cases show that courts, on the ground of cruelty, grant the wife a decree on much less evidence than they do the husband. That rests on sound principles, for acts and conduct on the part of a husband may well constitute cruelty to the wife causing her great distress, when similar acts and conduct on her part may not constitute cruelty to him, or cause him great mental distress. Before a decree is granted the husband on such grounds [mental cruelty], it ought to be a somewhat aggravated case.' Doe v. Doe, 48 Utah 200, I58 Pac. 78I. [1916]."

${ }^{56}$ See Levy v. Levy, 388 Ill. 179, 57 N.E.2d 366 (1944) indicating the greater degree of sympathy with which the courts view the physically weaker woman.

${ }^{50}$ Kammer v. Reed, 176 La. I091, 147 So. 357 (1933). 
called complainant such names as "mutt-face," "goofy," and "slut," it was held that such language was humiliating, inhuman, and sufficient to justify a divorce decree; whereas in Pennsylvania, ${ }^{57}$ which has a statute similar to that of Louisiana, the court maintained that where the wife publicly accused complainant husband of immoral conduct and constantly and vulgarly expressed her contempt for him, her behavior was too petty and trifling to upset a man. The courts seem to apply an objective test with respect to a male complainant and a subjective test with respect to a female complainant. For the man, the test might be stated thus: "would a reasonable man be so distressed by such conduct on the part of his wife?"; for the woman, it becomes, "should this woman, with all of her sensitivities and emotional instability, be forced to live with her husband in view of his treatment of her?"

To be sure, there may be some justification for holding that men are less affected by some charges and accusations than are women; yet, when the courts are consistently influenced by the sex of the complainant but fail to express it in their opinions, it does little to clarify the already confused divorce law.

Station in Life or Refinement of the Parties.

It is well recognized that courts, in hearing allegations of mental cruelty, are influenced by the intelligence, refinement, and delicacy of the complaining party. ${ }^{58} \mathrm{~A}$ crude person will not be upset by manifestations of unrefined habits, nor will an insensitive person be hurt by ordinary insult. ${ }^{50}$ Thus, a complainant who himself appears to be rude will not receive much sympathy from the court if he complains of rudeness on the part of his spouse, ${ }^{60}$ and the court will consider all characteristics of the parties in reaching its result. ${ }^{61}$ As the Pennsylvania

${ }^{67}$ Rose v. Rose, 124 Pa. Super, 437, 188 Atl. 595 (1936). See contra: Crabtrce v. Crabtree, 154 Ark. 401, 242 S.W. 804 (1922); Teal v. Teal, 324 Ill. 207,155 N.E. $28(1926)$.

${ }^{88}$ Stewart v. Stewart, 175 Ind. 412, 94 N.E. 564 (I9II); Valverde v. Valverde, 55 Nev. 82, 91, 26 P.2d 233, 237 (1933) wherein the court said: "Cruelty is a relative term. Its existance depends upon the character and refinement of the partics, and its determination must depend upon its own particular facts. What might be cruelty to one of refinement and of a sensitive nature would not be cruelty to one of a brutal disposition."

${ }^{60}$ Fleming v. Fleming, 95 Cal. 430, 30 Pac. 566 (1892); Marks v. Marks, 56 Minn. 264, 57 N.W. 65 I (1894); Kelly v. Kelly, I 8 Nev. 49, I Pac. 194 (1883).

${ }^{60}$ Zweig v. Zweig, 46 Ind. App. 594, 93 N.E. 234 (1910); Cunningham v. Cunningham, I87 Mich. 68, I53 N.W. 8 (1915); Emery v. Emery, 181 Mich. 146, 147 N.W. 452 (1914); Mosher v. Mosher, I6 N.D. 269, I13 N.W. 99 (1907) (profanity and obscene language by the wife).

${ }^{61}$ Scheibe v. Scheibe, 134 P.2d 835 (Cal. App. I943); Fleming v. Fleming, 95 Cal. 430, 30 Pac. 566 (1892); Kilpatrick v. Kilpatrick, 123 Conn. 218, 193 Atl. 765 
court stated in Nye's Appeal, "We do not divorce savages or barbarians because they act as such towards each other."

\section{Specific Acts or Courses of Conduct}

\section{Harsh or Humiliating Language.}

The continued use of profane and abusive language has been held to constitute sufficient mental cruelty upon which a divorce decree may be predicated. ${ }^{63}$ However, the evidence must be of such a nature as to convince the court that to compel the litigants to remain together as husband and wife would result in a most undesirable marital status. ${ }^{64}$ For example, while occasional fits of ill temper and rudeness resulting in abusive language are not sufficient grounds, ${ }^{65}$ continued demonstrations which indicate the futility of prolonging the existence of the union have been held to warrant a divorce decree. ${ }^{66}$

In those jurisdictions which require some resulting physical injury to the complainant, harsh or humiliating language which does not bring about such injury, or a reasonable apprehension thereof, is not, of course, a sufficient cause for divorce. ${ }^{6 \tau}$ Thus, in Massachusetts, ${ }^{68}$ where the court has continued to construe the divorce statute to require proof of such cruelty as either will cause injury to the life or health of complainant, or will create a danger or a reasonable apprehension of injury if the parties are compelled to remain together, few divorces are granted because of harsh or humiliating language.

Other courts, while ostensibly as stringent as the Massachusetts court in adhering to the classical requirements, ${ }^{69}$ have allowed inroads to be made into the conventional standards where it is shown that language which is offensive, per se, has been used. In Mosher v.

(1937); Mosher v. Mosher, I6 N.D. 269, II3 N.W. 99 (1907); Reinhard v. Reinhard, 96 Wis. $555,7 \times$ N.W. 803 ( 1897 ).

${ }^{02}$ Nye's Appeal, I26 Pa. 34I, I 7 Atl. 6r8 (I889).

${ }^{03}$ Koehler v. Koehler, 137 Ark. 302,209 S.W. 283 (r919) (husband continually called wife "whore"); Wirthman v. Wirthman, 225 Mo. App. 692, 39 S.W.2d 404 (193x); Brookhouse v. Brookhouse, 286 Mich, 151,281 N.W. 573 (1938).

${ }^{04}$ Brookhouse v. Brookhouse, 286 Mich. 151,281 N.W. 573 (1938).

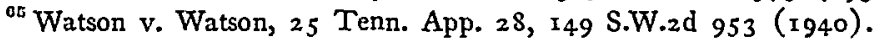

${ }^{00}$ Hockensmith v. Hockensmith, 286 Ky. 448, I5 I S.W.2d 37 (1941).

${ }^{07}$ Andrews v. Andrews, I20 Cal. I84, 52 Pac. 298 (I898); Dabelstein v. Dabelstein, 19r Iowa 808, I8 3 N.W. 385 (I92I); Hamren v. Hamren, I80 Md. 692, 26 A.2d 381 (I942); Krusinski v. Krusinski, I70 Mich. 561, I36 N.W. 593 (r912); Erwin v. Erwin, 23I S.W. 834 (Tex. Civ. App. r92 I).

${ }^{08}$ Brown v. Brown, 323 Mass. 332, 8I N.E.2d 820 (1948).

${ }^{\circ O}$ I.e., actual physical harm, a reasonable apprehension of injury, conduct endangering life, etc. 
Mosher, ${ }^{70}$ where the defendant wife habitually used profane language and related obscene stories to third persons in the presence of her much embarrassed husband, the court granted a divorce when it was merely shown that the husband's shy personality was affected by that conduct. Nevertheless, in most states where there has been considerable divorce litigation involving harsh and humiliating language, it has been held that words alone are insufficient. Thus, in Illinois, ${ }^{71}$ Tennessee, ${ }^{72}$ Maryland, ${ }^{73}$ and Arkansas ${ }^{74}$ the courts have declined to grant a decree in the absence of some resulting injury to complainant but have displayed a willingness to accept even minute evidence of injury as a sufficient peg upon which to hang their decree. ${ }^{75}$ Colorado, accepting what perhaps is a more realistic view, has discarded the resulting injury requisites and holds that words, in themselves, may constitute mental cruelty. ${ }^{70}$ But which view is better-that of Colorado, which manifests its true rationale in the written opinion, or that of most of the other courts, which dodges the real issues, is a matter that can be decided only with a view toward the desired results. If the desired result is to exercise strict control over divorce litigation, the view of the majority is more efficacious. If, on the contrary, an intelligible standard or guide is the objective, then the open expression of the Colorado court is the more effective approach.

Denial of Conjugal Rights.

Usually, the refusal by one spouse to engage in sexual intercourse is not, of itself, a ground for divorce. ${ }^{77}$ The circumstances surrounding

\footnotetext{
${ }^{70}$ Mosher v. Mosher, x6 N.D. 269, 1 13 N.W. 99 (x907). See also: Rader v. Rader, $x_{3} 6$ Iowa 223, $x_{3}$ N.W. 817 (1907); Carpenter v. Carpenter, 30 Kan. 712, 2 Pac. 122 (1883); Outlaw v. Outlaw, 118 Md. 498, 84 Atl. 383 (1912); Humber v. Humber, 109 Miss. 216, 68 So. 161 (1915); Morris v. Morris, xo8 Misc. 228, 177 N.Y. Supp. 600 ( $19 \times 9)$.

${ }^{71}$ Jackson v. Jackson, 294 Ill. App. 552, 14 N.E.2d 27 x (x938); Moore v. Moore, 262 Ill. 177, r 99 N.E. 98 ( 1935 ).

${ }^{22}$ Watson v. Watson, 25 Tenn. App. 28, 149 S.W.2d 953 (x941).

${ }^{73}$ Eberwein v. Eberwein, 65 A.2d 792 (Md. x949); Smith v. Smith, 63 A.2d 628 (Md. x949); Brett v. Brett, xo9 Md. 704, 182 Atl. 305 (1936).

${ }^{73}$ Kientz v. Kientz, ro4 Ark. $38 \mathrm{r}, 149$ S.W. 86 (1912).

${ }^{75}$ Note, 5 ARK. L. REv. 419 (195 I).

${ }^{76}$ Miller v. Miller, 9o Colo. 428, 9 P.2d 616 (1932).

${ }^{77}$ Underwood v. TJnderwood, $27 x$ Fed. 553 (D.C. Cir. $x 92 x$ ) ; Pinnebad v. Pinnebad, 134 Ga. 496, 68 S.E. 73 (1910); Wagner v. Wagner, 203 Mich. 328, 168 N.W. xorg (x918); Gilson v. Gilson, xr3 N.J.Eq. 32, x66 Atl. xIx (x933); Taylor v. Taylor, 142 Pa. Super. 441, I6 A.2d 65I (1940); Roush v. Roush, 90 W. Va. 49I, I I I S.E. 334 (r922). See also Lohmuller v. Lohmuller, $x_{35}$ S.W. $75 x, 753$ (Tex. Civ. App. IgII) wherein the court said: "[I]t has been uniformly held that a denial of sexual intercourse of itself, even when persisted in for a long time, will not be a ground for divorce, unless it injures the health."
} 
the denial may, however, present such an appealing case that the courts will grant a divorce by maintaining that the refusal constitutes mental cruelty. ${ }^{78}$ The courts apparently look closely at the reasons for the conduct of the offending spouse and at the duration of the refusal to cohabit. If there seems to be a spiteful refusal ${ }^{79}$ on the part of one of the spouses, as opposed to a refusal for sound reasons ${ }^{80}$ (e.g., health), ${ }^{81}$ a divorce is likely to follow. For example, in Michigan, where a wife declined to live with her husband for three years because she did not like him and wanted to annoy him, a divorce was granted to the husband on the ground that such treatment was extreme cruelty; ${ }^{82}$ and it has been concluded that, where a wife, without cause, refused to cohabit for I2 years, there was sufficient cruelty to justify a divorce in the absence of any other statutory requirements. ${ }^{83}$ This view, while not wholly in accord with the general case law $^{84}$ is nevertheless supported by authorities in the field ${ }^{85}$ and appears to be becoming more widely accepted by the courts. ${ }^{88}$

It is where the denial or marital rights is coupled with other factors, none of which alone would justify a divorce in accordance with statutory standards, that the courts are most apt to pigeon-hole the conduct into the category of mental cruelty. ${ }^{87}$ In a Michigan case, ${ }^{88}$ where a wife called complainant vulgar names and refused to cohabit for several years, a divorce was granted. The courts of Florida, ${ }^{89}$ Missouri, ${ }^{90}$ and

${ }^{78}$ Another category wherein such conduct is often placed in order that a divorce might be granted is that of desertion, either actual or constructive. See note 175 A.L.R. 708, 7xI (1948).

${ }^{70}$ Case v. Case, 159 Mich. 49x, 124 N.W. 565 (1910); Campbell v. Campbell, I49 Mich. I47, II2 N.W. 480 (I907); Tupper v. Tupper, I47 Atl. 633 (N.J.Eq. 1 929); cf. Severns v. Severns, ro7 Ill. App. I4I (1903); Platt v. Platt, 38 Pa. Super. 55 I (1908).

${ }^{80}$ Bishop v. Bishop, I 33 Wash. 522, 233 Pac. 918 (1925).

${ }^{81}$ Rausch v. Rausch, 146 Pa. Super. 342, 22 A.2d 221 (1941). See also: Ritter v. Ritter, ro3 Cal. App. 583, 587,284 Pac. 950, 952 (1930) wherein the court said: "A refusual of intercourse can be regard as cruelty only when without just or proper cause, and when the health and bodily condition of both spouses would justify such intercourse."

${ }^{82}$ Case v. Case, 159 Mich. 49I, 124 N.W. 565 (1910).

${ }^{83}$ Nordlund v. Nordlund, 97 Wash. 475, 166 Pac. 795 (1917).

${ }^{84}$ Kingsley, Divorce in Minnesota, I6 Minn. L. Rev. 264 (1931).

${ }^{85}$ Ibid.

${ }^{80}$ See note, 175 A.L.R. 708 (1948).

${ }^{87}$ Currie v. Currie, 120 Fla. 28, 162 So. 152 (1935).

${ }^{88}$ Waldhorn v. Waldhorn, 165 Mich. 130 , 130 N.W. I99 (1911). See also Menzer v. Menzer, 83 Mich. 319,47 N.W. 219 (1890) for earlier indications of such attitudes.

${ }^{80}$ Supra note 87.

${ }^{80}$ Casey v. Casey, 180 Mo. App. 605, 163 S.W. 569 (1914). 
West Virginia ${ }^{91}$ likewise have considered denials of sexual intercourse, along with other acts, as constituting mental cruelty upon which a divorce decree might be predicated.

The denial of another marital right which not infrequently appears as the basis of a divorce action is that of procreation. Generally it is held that the mere refusal to have children, over the objections of the other spouse, does not constitute cruelty, ${ }^{92}$ nor does the refusal of one spouse to engage in sexual intercourse unless contraception is practiced authorize the granting of a divorce. ${ }^{93}$

\section{False charges of marital misconduct.}

Although there is some early authority to the effect that false charges of marital misconduct are not, in themselves, sufficient proof of cruelty to sustain a divorce decree, ${ }^{94}$ the great weight of authority today supports a contrary view. ${ }^{95}$ It must be shown that the accusations were made in bad faith ${ }^{06}$ and without probable cause, ${ }^{07}$ although it has been held that the absence of probable cause raises a presumption of bad

${ }^{21}$ Cottle v. Cottle, 4o S. E. 2d 863 (W. Va. 1946); Croll v. Croll, ro6 W. Va. 691, 146 S.E. 880 (1929); Perine v. Perine, 92 W. Va. 530, 114 S.E. 871 (1922).

${ }^{82}$ Avoidance of procreation has been held to constitute desertion or fraud bised upon an implied promise. See Note, 4 A.L.R.2d 227 (1949).

${ }^{93}$ Thomas v. Thomas, 2 19 Ala. 196, 12 I So. 7 ro (1929); Lohmuller v. Lohmuller, 135 S.W. 75 I (Tex. Civ. App. I9II).

${ }^{84}$ Farnham v. Farnham, 73 Ill. 497 (1874); Holyoke v. Holyoke, 78 Me. 404, 6 Atl. 827 (1886); Owens v. Owens, 96 Va. 191, 31 S.E. 72 (1898).

${ }^{95}$ Folmar v. Folmar, 69 Ala. 84 (1881); Anderson v. Anderson, $68 \mathrm{Cal}$. App. 218 , 228 Pac. 715 (1924); Babcock v. Babcock, 1x7 Conn. 310, 167 Atl. 815 (1933); Whetherington v. Whetherington, 57 Fla. 551 , 49 So. 549 (I909); Miller v. Miller, 139 Ga. 282, 77 S.E. 21 (1913); Eward v. Eward, 72 Ind. App. 638, 125 N.E. 468 (I919); Blazek v. Blazek, 216 Iowa 775, 249 N.W. I99 (I933); Bracken v. Bracken, I15 Kan. 494, 223 Pac. 288 (1924); Sandlin v. Sandlin, 289 Ky. 290, 158 S.W.2d 635 (I942); Vicknari v. Terracina, I64 La. II7, II3 So. 787 (1927); Poole v. Poole, 176 Md. 696, 6 A.2d 243 (1939); Brookhouse v. Brookhouse, 286 Mich. 151, 281 N.W. 573 (1938); Hertz v. Hertz, I26 Minn. 65, 147 N.W. 825 (1914); Holm v. Holm, 25 I S.W. 130 (Mo. App. 1923); Gordon v. Gordon, 77 N.H. 597, 92 Atl. 546 (1914); Feybusch v. Feybusch, 1 10 N.J.Eq. 358, 160 Atl. 386 (1932); Pearson v. Pearson, 104 Misc. 675, 173 N.Y. Supp. 563 (1918); Reed v. Reed, 182 Okla, 149, 77 P.2d 30 (1938); Dietz v. Dietz, 158 Ore. 13, 72 P.2d 60 (1937); Beard v. Beard, I58 Tenn. 437, I4 S.W.2d 745 (r929); Boydston v. Boydston, 290 S.W. 927 (Tex. Civ. App. 1927); Doe v. Doe, 48 Utah 200, 158 Pac. 781 (1916); Morris v. Morris, 57 Wash. 465, 107 Pac. I86 (I910).

${ }^{98}$ Rowe v. Rowe, 84 Kan. 696, II5 Pac. 553 (1911) ;- Elswick v. Elswick, 130 Okla. 42, 265 Pac. 121 (1928).

${ }^{87}$ Barnett v. Barnett, 292 Ky. 840, I68 S.W. 2 d 17 (1943); Poole v. Poole, 176 Md. 69, 66 A.2d 243 (1939); Gindorff v. Gindorff, 295 Mich. 469, 295 N.W. 229 (1940); Parman v. Parman, 94 Ore. 307, 185 Pac. 922 (1919). See also Barton v. Barton, 97 N.J.Eq. 404, 128 Atl. 798 (1925). 
faith. ${ }^{98}$ In addition to these requirements some states adhere to the classical requisites of danger to the health of the complainant ${ }^{99}$ or danger to life, ${ }^{100}$ while other states allow evidence of mental anguish to suffice. ${ }^{101}$ In Williams $v$. Williams, ${ }^{102}$ for example, where complainant's wife circulated letters accusing complainant of illicit relations with church women, as a result of which complainant was requested to leave the church, the court granted a divorce without any showing of other injury resulting from the false charges.

Charges of unchastity may constitute cruelty whether privately ${ }^{103}$ or publicly ${ }^{104}$ made. If the accusations are communicated to third persons, it is not necessary that they be believed, ${ }^{105}$ for it is the effect that the charges have upon the complainant and not the reactions of others that is the test. ${ }^{106}$ Further, there need not be continued or repeated accusations, as a single charge of adultery can have a sufficiently damaging effect. ${ }^{107}$ A single act of adultery, once condoned, will not license accusations predicated upon that act. ${ }^{108}$ The fact that the accusations were made while the defendant was intoxicated ${ }^{109}$ or was in a fit of rage or insanity ${ }^{110}$ does not negative the legal effect of the charges.

Accusations of marital misconduct which appear in the pleadings of a divorce action may constitute cruelty which, in itself, might justify a divorce decree. ${ }^{111}$ If, however, it appears that the defendant had reasonable grounds for the accusations or that they were made in good faith,

${ }^{88}$ Bracken v. Bracken, I I 5 Kan. 494, 223 Pac. 288 (1924); Wiggins v. Wiggins, 268 Ky. 352, 104 S.W.2d 1097 (1937).

${ }^{00}$ Sylvis v. Sylvis, I1 Colo. 319, I7 Pac. 912 (1888); Miller v. Miller, 139 Ga. 282, 77 S.E. 21 (1913); Stover v. Stover, 94 N.J.Eq. 703, 120 Atl. 788 (1923).

${ }^{100}$ Harkins v. Harkins, 99 N.W. 154 (Iowa 1904).

${ }^{101}$ O'Brien v. O'Brien, I or Conn. 8o, 124 Atl. 8 I 6 (1924).

${ }_{102} 37$ Ark. I 76 (1870).

${ }^{103}$ Brandt v. Brandt, ${ }_{7} 8$ Cal. 548, I74 Pac. 55 (1918); Ward v. Ward, Io3 IIl. 477 (1882); Waltermire v. Waltermire, r1o N.Y. 183,17 N.E. 739 (1888); Boydston v. Boydston, 290 S.W. 927 (Tex. Civ. App. 1927). Contra: Harkins v. Harkins, 124 Iowa 69,99 N.W. I 54 (1904).

${ }^{104}$ See Note, 143 A.L.R. 623 (1943).

${ }^{105}$ Shaw v. Shaw, 122 Cal. App. I72, 9 P.2d 876 (1932).

${ }^{100} I d$. at 878 .

${ }^{207}$ Anderson v. Anderson, 68 Cal. App. 218,228 Pac. 715 (1924).

${ }^{108}$ Williams v. Williams, 199 Ky. 259, 250 S.W. 982 (1923).

${ }^{100}$ Harl v. Harl, 24 Ky. L. Rep. 2163,73 S.W. 756 (1903); Pfannebecker v. Pfannebecker, 133 Iowa 425, I ro N.W. 618 (1907); Miller v. Miller, 89 Neb. 239, 131 N.W. 203 (1911); Elswick v. Elswick, r30 Okla. 42, 265 Pac. I21 (1928).

${ }^{110}$ Champagne v. Duplottis, 147 La. 110, 84 So. 5 I 3 (1920).

${ }^{111}$ Wilson v. Wilson, 97 Ark. 643, 134 S.W. 963 (1911); Bush v. Bush, 245 Ky. 172, 53 S.W.2d 352 (1932); Clough v. Clough, 1 32 Neb. 748,273 N.W. 3 I (1937); La Follett v. La Follett, 138 Ore. $4 x x, 6$ P.2d ros $_{5}$ (1932); Owen v. Owen, 178 Wis. 609,190 N.W. ${ }_{3}^{6} 3$ (1922). 
there is no cruelty. ${ }^{112}$ Thus, where the husband's complaint charged lewd and lascivious conduct on his wife's part, the court found no cruelty when it was shown that the charges were not made in bad faith. ${ }^{113}$ Where both parties falsely and in bad faith accuse each other of infidelity, neither party may be granted a divorce on the ground of cruelty by reason of those accusations. ${ }^{114}$

The courts usually treat the complainant wife with greater sympathy than the husband, with regard to accusations of marital misconduct. ${ }^{115}$ The courts take notice of a double standard regarding sex activity and conclude that men are much less sensitive than are women concerning their reputations for chastity and faithfulness. ${ }^{110}$

\section{Miscellaneous conduct.}

The following specific acts have been held to constitute mental cruelty justifying the granting of a divorce decree. While no less important than the types of conduct set forth above, they are not so complex as to require more than brief attention.

Communications by one spouse of venereal disease has been held to constitute mental cruelty ${ }^{117}$ warranting divorce. ${ }^{118}$ The complainant must establish that the diseased spouse was aware of his condition ${ }^{110}$ and that he made demands ${ }^{120}$ for sexual intercourse with knowledge ${ }^{121}$ that the disease was infectious. ${ }^{122}$

\footnotetext{
${ }^{112}$ Steele v. Steele, 237 Mich. 639, 213 N.W. 66 (1927)

${ }^{113}$ Pennington v. Pennington, 294 Ky. 84, I 7 I S.W.2d ro (1943).

${ }_{114}$ Biebisheimer v. Biebisheimer, 202 Iowa 668, 210 N.W. 896 (1926).

${ }^{115}$ See Note, 143 A.L.R. 623, 655 (1943).

${ }^{116}$ Miller v. Miller, 89 Neb. 239, 131 N.W. 203 (I911); Elswick v. Elswick, 130 Okla. 42, 265 Pac. I2I (1928); Doe v. Doe, 48 Utah 200, 158 Pac. 781 (1916); Roush v. Roush, 90 W. Va. 49 1, III S.E. 334 (I922).

${ }^{117}$ Communication of venereal disease has also been subsumed under physical cruclty.

${ }^{118}$ Carbajal v. Fernandez, 130 La. 812, 58 So. 581 (1912); Holthoeffer v. Holthoeffer, 47 Mich. 260, I I N.W. I50 (1882); Darling v. Darling, I8 I Mo. App. 211,167 S.W. 1166 (I914); Wagner v. Wagner, 80 Ore. 256, I56 Pac. 1037 (1916). ${ }_{119}$ Anonymous, I7 Abb. N.C. 231 (N.Y. 1886 ).

${ }^{120}$ Kline v. Kline, 179 Md. I0, 16 A.2d 924 (1940); Lazarwitz v. Lazarwitz, 102 N.J.Eq. 132, 139 Atl. 88I (1928) (attempt to force wife to have sexual intercourse while knowing of diseased condition); Abramowitz v. Abramowitz, 140 N.Y. Supp. 275 (1913); McMahen v. McMahen, I86 Pa. 485, 40 Atl. 795 (1898). But mere requests do not constitute cruelty. Bowman v. Bowman, 6 W.W. Harr. 84, I 7 I Atl. 444 (Del., 1934).

${ }^{121}$ Knowledge is not necessarily actual knowledge but facts from which a reasonable man would conclude the presence of venereal disease. Carbajal v. Fernandez, 130 La. 812,58 So. 581 (1912).

${ }^{122}$ Hanna v. Hanna, 3 Tex. Civ. App. 51, 2 I S.W. 720 (1893) wherein the court held that the question of scienter was a matter of fact and not a question of law.
} 
Association with objectionable persons ${ }^{123}$ or compelling one's spouse to associate with undesirable or lewd persons ${ }^{124}$ has been held to constitute mental cruelty. This type of cruelty is frequently the subject of litigation where one of the spouses invites undesirable persons to be house guests for long periods. ${ }^{125}$

Although a husband is not generally chargeable with the misconduct of third persons, it has been held that he owes to his wife the duty of protecting her from the abuse of others, and a divorce may be granted upon a showing of his failure to do so. ${ }^{126}$

An unjustified refusal by one spouse to speak to the other spouse accompanied by an otherwise disagreeable attitude ${ }^{127}$ will entitle the complainant to a divorce. ${ }^{128}$

An unfounded charge of insanity ${ }^{129}$ or a malicious attempt to have one's spouse committed to an asylum ${ }^{130}$ may constitute cruelty. The test is whether the charge or attempt was made in good faith with the welfare of the complainant in mind. ${ }^{331}$

As a general proposition religious differences do not constitute cruelty unless one of the spouses is so fanatical as to render family happiness impossible. ${ }^{132}$ In cases where actual injury to one spouse results from the religious fanaticism of the other a divorce will be granted. ${ }^{133}$

The "cruelty" may be confined to the relation between the spouses. It may further be marked by affirmative physical and mental factors, as in the case of an unnatural sex act, ${ }^{134}$ affirmative mental factors with a possibility of physical repercussions, as where defendant is in a state of habitual intoxication; ${ }^{135}$ or exclusively affirmative mental aspects, as in

\footnotetext{
${ }^{123}$ Frith v. Frith, 189 Iowa 201, 175 N.W. 76x (1920).

${ }^{126}$ Hooker v. Hooker, 65 Fla. 53, 61 So. 121 ( $\left.19 \times 3\right)$; Craig v. Craig, 129 Iowa 192,105 N.W. 446 (x905); Goff v. Goff, 60 W.Va. 9, 53 S.E. $7^{69}$ (1906).

${ }^{126}$ Craig v. Craig, 129 Iowa 192, 105 N.W. 446 (1905).

${ }^{120}$ Snyder v. Snyder, 98 Misc. 43I, 162 N.Y. Supp. 607 (1917); Sayles v. Sayles, 4I R.I. 170, 103 Atl. 225 (1918).

${ }^{127}$ Hiecke v. Hiecke, I63 Wis. 171,157 N.W. 747 (1916).

${ }^{128}$ Ibid.

${ }^{120}$ Michels v. Michels, 120 Me. 395, I15 Atl. I6ะ (192x).

${ }^{130}$ Andrews v. Andrews, 120 Cal. 184,52 Pac. 298 ( 1898 ).

${ }^{131}$ Schutte v. Schutte, go W. Va. 787 , IrI S.E. 840 ( 1922 ).

${ }^{132}$ Krauss v. Krauss, I6 63 La. 218 , III So. 683 ( 1927 ).

${ }^{133}$ Robinson v. Robinson, 66 N.H. 600,23 Atl. 362 (x $89 x$ ) where husband suffered illness because wife who was a Christian Scientist denied him medical attention.

${ }^{134}$ Doolin v. Doolin, 211 Ky. 207,277 S.W. 243 (r925) (father having intercourse with daughter resulting in daughter becoming pregnant); Crutcher v. Crutcher, 86 Miss. 231, 38 So. 337 (1905) (sodomy). But see Wood v. Wood, I4I Mass. 495, 6 N.E. 54 I ( 1886 ) wherein wife was denied a divorce because husband engaged in masturbation, but she was not forced to be present during the acts.

${ }^{136}$ Bennett v. Bennett, 55 Cal. App. 268, 203 Pac. 162 (192 I); Balfe v. Balfe, r65
} 
the case of continuous nagging. ${ }^{136}$ But "cruelty" need not be confined to, or perhaps even immediately identified with, the spouse-to-spouse relation. Affirmative factors are present where spouse $A$ abuses the children thus causing distress to spouse B. ${ }^{137}$ Negative factors-failure to do one's duty ${ }^{138}$-are involved where spouse $A$ permits his relatives to abuse spouse B. ${ }^{139} \quad \mathrm{~A}$ may be held to a duty to prevent the abuse and to protect and to defend $B$ under such circumstances. ${ }^{140}$

After reading this list of possible mental cruelties one may wonder whether a husband and wife can live together for any length of time without supplying each other with grounds for divorce. It may appear that marriage takes on some of the aspects of a status by sufferance, and the question arises whether the courts should not require the plaintiff, in addition to proving mental cruelty, to satisfy the court that he has done everything within reason to make a successful marriage. ${ }^{141}$

La. 283 , r15 So. 489 (r928); Hall v. Hall, r72 Mich. 210,137 N.W. 536 (1912); Maxwell v. Maxwell, 69 W. Va. 4r4, 7r S.E. 57x (1911). Contra: Sedgwick v. Sedgwick, 5o Colo. I64, I14 Pac. 488 (Igri); Cruikshank v. Cruikshank, II5 N.J.Eq. 322, 170 Atl. 659 (1934).

${ }^{138}$ Barngrover v. Barngrover, 57 Cal. App. 43, 206 Pac. 461 (r922) (continuous nagging for ten years); Putnam v. Putnam, 86 Mont. 135, 282 Pac. 855 (1929). But cf. Bird v. Bird, 171 Wis. 219, I 77 N.W. 4 (1920).

${ }^{137}$ Poe v. Poe, 149 Ark. 62, 23 I S.W. 198 (1921) (mistreatment of stepchild with intent to upset parent); Williamson v. Williamson, 183 Ky. 435, 209 S.W. 503 (1919) (attempt by husband to get rid of child by wife's former marriage); Romero v. Dautrielle, $x 6_{3}$ La. 597 , I $\times 2$ So. 498 (1927); Miller v. Miller, 54 Nev. 44 , I I P.2d 1088 (1932). But the use of reasonable force in order to discipline his children is not cruelty to one's spouse. Kruschke v. Kruschke, 103 Ore. 601, 205 Pac. 973 (1922); Loring v. Loring, I7 Tex. Civ. App. 95, 42 S.W. 642 (1897).

${ }^{138}$ Inman v. Inman, 196 Iowa 845,195 N.W. $5_{3}$ (1923); Mecke v. Mecke, 126 Kan. 760, 27 I Pac. 275 (1928); Metcalf v. Metcalf, 166 Ore. 644, 114 P.2d 547 (194r) (failure to provide medical care).

${ }^{230}$ Day v. Day, 84 Iowa 22x, 50 N.W. 979 (1892); Thompson v. Thompson, 205 Mich. 124, I7I N.W. 347 (1919); Dakin v. Dakin, I Neb. 457, 95 N.W. 781 (rgor); Fraser v. Fraser, 87 N.J.Eq. 633, 101 Atl. 58 (x91 7 ); Nickerson v. Nickerson, 34 Ore. I, 54 Pac. 277 (1898); Schuster v. Schuster, 88 Utah 257, 53 P.2d 428 (1936); Hutchins v. Hutchins, 93 Va. 68, 24 S.E. 903 (1896). Contra, Artigues v. Artigues, 172 La. 884, 135 So. 665 (1931).

${ }^{1 * 0}$ See cases cited note 126 supra.

${ }^{111}$ Sayre, Divorce for the Unworthy: Specific Grounds for Divorce, 18 Law \& CoNTEMP. PROB. 26 (1953). 


\section{APPENDIX}

Table of Statutes

* Only divorces a mensa et thoro on the ground of mental cruelty.

JURISDICTION

ALABAMA

ALASKA*

ARIZONA

ARKANSAS

CALIFORNIA

COLORADO

CONNECTICUT

DELAWARE

DISTRICT OF

COLUMBIA*

FLORIDA

GEORGIA

IDAHO
StatuTE

Ala. Code tit. $34, \S 20$ (1940)

ALASKA COMP. LAWS

ANN. \& 56-5-7 (1949)
ARIz. CODE ANN. § 27813 (1939)

ARK. Stat. $\S 34-1202$ (1947)

Cal. Civ. Code I37, 94

(Deering, 1949)

Colo. Stat. AnN. c. 56, § I (1935)

Conn. Gen. Stat. $\S 7327$ (1949)

DEL. REv. CoDE $§ 3499$ (1935)

D.C. CODE § I 6-403

(1940)

Fla. Stat. ANn. $§ 65.04$ (1943)

GA. CODE ANN. § 30I02(10) (1936)

IDAHO CODE $\S \quad 32-603$ (1947)

\section{DESCRIPTIVE WORDS}

Cruelty attended by actual violence which endangers life or health of reasonable apprehension thereof.

Cruel and inhuman treatment calculated to impair health or endanger life ... personal indignities rendering life burdensome or incompatibility of temperament.

Conduct on part of husband rendering cohabitation unsafe.

Cruel and barbarous treatment as to endanger the life of the other, or shall offer such indignities to the person of the other as shall render his or her condition intolerable.

Extreme cruelty. Extreme cruelty is wrongful infliction of grievous bodily injury or grievous mental suffering.

Extreme and repeated cruelty ... such cruelty may consist of the infliction of mental suffering....

Intolerable cruelty.

Extreme cruelty ... such as to endanger life or health or render cohabitation unsafe.

Cruelty.

Extreme cruelty.

Cruel treatment.

Extreme cruelty. 
ILLINOIS

INDIANA

IOWA

KANSAS

KENTUCKY

LOUISIANA

MAINE

MARYLAND*

MASSACHUSETTS

MICHIGAN*

MINNESOTA

MISSISSIPPI

MISSOURI

MONTANA

NEBRASKA

NEVADA
ILL. REV. STAT. c. 40, Extreme and repeated cruelty.

\&I (195I)

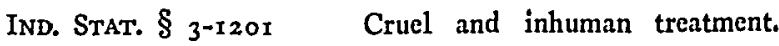

(Burns, 1933)

IOWA CODE ANN.

$\S 598.8$ (1950)

KaN. GeN. STAT. $§ 60-$ Extreme cruelty.

I5OI (1950)

KY. REV. STAT.

$\S 403.020$ (1948)

LA. Civ. CODE $§ 139$

(Dart, 1945)

ME. Rev. StaT. c. 153, Extreme cruelty.

\& 55 (1944)

MD. CoDE ART. 16, $\S_{34}$ Cruelty of treatment. . .

(1951)

Mass. ANn. Laws c. Cruel and abusive treatment. 208, \& × (1933)

Mich. Comp. Laws

$\S 552.7$ (1948)

Minn. Stat. Ann. $\S 5 \times 8.06(1947)$

Miss. CoDE $\S 2735$

(1942)

Mo. ReV. STAT.

$\S \S 1514,1521$ (1942)

Mont. Rev. Code c. I 85 ( 1945$)$

Neb. Rev. Stat.

§ 42-302 (1943)

NEv. CoMp. LaWS

$\S 9460$ (1929)
Cruel beating or injury, or attempt at injury as indicites outrageous temper, or probable danger to life or great bodily injury from remaining together.

Cruel treatment or outrages such as to render living together in. supportable.

Extreme cruelty, whether by personal violence or other means.

Cruel and inhuman treatment.

Habitual cruel and inhuman treatment.

Cruel or barbarous treatment as to endanger life. Indignities.

Repeated publications or utter. ances of false charges against unchastity or the infliction of grievous mental suffering for one year, reasonably calculated to destroy happiness, defeat the purpose of marriage, or render married relations intolerable.

Extreme cruelty, whether by personal violence or by other means.

Extreme cruelty. 
NEW HAMPSHIRE N.H. REv. LAWS c. 339, Extreme cruelty.

§ 6 (1942)

NEW JERSEY

NEW MEXICO

NEW YORK*

NORTH CAROLINA*

NORTH DAKOTA

OHIO

OKLAHOMA

OREGON

PENNSYLVANIA

RHODE ISLAND

SOUTH CAROLINA

SOUTH DAKOTA

TENNESSEE
N.J. Stat. ANN. § 2:50-2 (1939)

N.M. STAT. § 25-70I (1941)

N.Y.C.P.A. $§ 1161$ (1948)

N.C. GEN. Stat. § 50-7 (1943)

N.D. ReV. CODE \& 14-0503 (I943)

OHIO. Rev. CODE \$ 3105.01 (Page, 1954)

OKLa. STAT. tit. I2, $\S$ I27I (I94I)

Ore. Comp. LaWs ANN. $\S$ 9-907 (1940)

PA. STAT. tit. 23, § I0 (Purdon, 1930)
Extreme cruelty.

Cruel and inhuman treatment.

Cruel and inhuman treatment.

Cruel or barbarous treatment as endangers the life of the other. Indignities to the person.

Extreme cruelty.

Extreme cruelty.

Extreme cruelty.

Cruel and inhuman treatment or personal indignities rendering life burdensome.

Cruel and barbarous treatment, endangering the life of the injured and innocent spouse. Such indignities to the person of the injured and innocent spouse as to render his or her condition intolerable or life burdensome.

R.I. Gen. Laws c. 416, Extreme cruelty.

$\S_{2}(1938)$

S.C. CODE $§ 20-101$

(I952)

S.D. CODE § 14.0703 (1939)

TENN. Code $§ 8427$

(Williams, 1934)
Physical cruelty.

Extreme cruelty . . . infliction of grievous bodily injury or grievous mental suffering.

Cruel and inhuman treatment as renders cohabitation unsafe and improper, and in the case of the wife, to be under the domination and control of the husband. That husband has offered such indignities to the wife's person as to render her condition intolerable. ... 
104

TEXAS

UTAH

VERMONT

VIRGINIA*

WASHINGTON

WISCONSIN

WYOMING
Tex. Civ. Stat.

Art. 4629 (Vernon, 1940)

UtAh Code ANn. $\S_{40-3-1 \text { (1 } 943)}$

VT. STAT. ReV. $\S 3206$ (1947)

VA. CODE ANN. \$ 20-95 (1950)

WASH. REV. STAT. $\S 9_{82}$ (Remington, 1932)

WEST VIRGINIA

W. VA. CoDE $\S 4704$ (r949)

WIs. STAT. § 247-07 (1949)

Wyo. Comp. Stat. §3-5905 (x945)
Excess, cruel treatment or outrages toward the other, if such ill treatment is of such a nature as to render their living together insupportable.

Cruel treatment to the extent of causing bodily injury or great mental distress.

Intolerable severity.

Cruelty.

Cruel treatment or personal indignities rendering life burdensome.

Cruel and inhuman trentment, or reasonable apprehension of bodily harm, and a false charge of prostitution. ...

Treatment of the wife by the husband has been cruel and in. human, whether practiced by using personal violence or by other means, or where the wife shall be guilty of like cruelty to her husband or shall be given to intoxication.

Extreme cruelty. . . . Indignities.

SANFord I. Halberstadter 